\title{
Trawling disturbance on benthic ecosystems and conse- quences on commercial species: a northwestern Mediterranean case study
}

\author{
Alba Muntadas ${ }^{1}$, Montserrat Demestre ${ }^{1}$, Silvia de Juan ${ }^{2}$, Chris L.J. Frid ${ }^{3}$ \\ ${ }^{1}$ Intitut de Ciencies del Mar, Passeig Marítim de la Barceloneta 37-49, 08003 Barcelona, Spain. \\ E-mail: amuntadas@icm.csic.es \\ ${ }^{2}$ National Institute of Water and Atmospheric Research (NIWA), PO Box 11-115, Hamilton, New Zealand \\ ${ }^{3}$ School of Environmental Sciences, University of Liverpool, Brownlow Street, Liverpool, L69 3GP, UK.
}

\begin{abstract}
Summary: Trawling is known to disturb benthic communities and habitats, which may in turn indirectly affect populations of commercial species that live in close association with the seabed. The degree of impact on both benthic communities and demersal species depends on the fishing effort level. This may vary over the year because of the fleet dynamics, which are in turn normally driven by the main target species' life cycle. In this study we describe changes in benthic functional components of a northwestern Mediterranean fishing ground that represents a recruitment area for an important target species (red mullet, Mullus barbatus). This fishing ground experiences a varying intensity of fishing effort over the year and benthic functional components under different levels of trawling were compared with an unfished, control area. Traits related to sexual maturity and life span for infauna and body size and life span for epifauna were found to vary with fishing activity. Potential effects of these changes on ecological functioning and the impact on red mullet population are discussed. The development of fisheries management plans under an ecosystem based fisheries management (EBFM) requires the links between target species and benthic communities' disturbance due to fishing practices to be explicitly considered.
\end{abstract}

Keywords: benthos; BTA; functioning; mullet fisheries; trawling; NW Mediterranean.

Perturbación de la pesca de arrastre en ecosistemas bentónicos y sus consecuencias en las especies comerciales: un caso de estudio en el Mediterráneo Noroccidental

Resumen: Se sabe que la pesca de arrastre provoca una perturbación en los hábitats y ecosistemas bentónicos, lo cual a su vez puede afectar indirectamente a las poblaciones de especies comerciales que viven en estrecha relación con el fondo marino. El nivel de impacto en las comunidades bentónicas y en las especies comerciales depende en ambos casos del nivel de esfuerzo pesquero. Este esfuerzo puede variar a lo largo del año, ya que la dinámica de la flota está normalmente determinada por el ciclo vital de las especies objetivo. En este estudio se describen cambios en los componentes funcionales del bentos de un caladero del Mediterráneo noroccidental que constituye un área de reclutamiento para una importante especie objetivo como es el salmonete de fango (Mullus barbatus). Este caladero experimenta variaciones de la intensidad de esfuerzo pesquero a lo largo del año. Los componentes funcionales del bentos sometidos a estos niveles variables de esfuerzo fueron comparados con los de una zona control que no está sometida a la pesca. Los resultados muestran que características relacionadas con la madurez sexual y el periodo de vida para la infauna y con el tamaño corporal y el periodo de vida para la epifauna variaron con el esfuerzo pesquero. En el trabajo se discuten los efectos potenciales de estos cambios en la funcionalidad del ecosistema y su impacto en la población de salmonete. Para desarrollar planes de gestión pesquera en el marco de la gestión basada en el ecosistema (EBFM) se requiere que estas relaciones entre la perturbación de las comunidades bentónicas debida a la pesca y las especies objetivo sean claramente consideradas.

Palabras clave: bentos; BTA; funcionalidad; pesquería del salmonete; pesca de arrastre; Mediterráneo noroccidental.

Citation/Como citar este artículo: Muntadas A., Demestre M., de Juan S., Frid C.L.J. 2014. Trawling disturbance on benthic ecosystems and consequences on commercial species: a northwestern Mediterranean case study. In: Lleonart J., Maynou F. (eds), The Ecosystem Approach to Fisheries in the Mediterranean and Black Seas. Sci. Mar. 78S1: 53-65. doi: http:// dx.doi.org/10.3989/scimar.04024.19A

Editors: Jordi Lleonart and Francesc Maynou.

Received: September 30, 2013. Accepted: January 10, 2014. Published: March 28, 2014.

Copyright: () 2014 CSIC. This is an open-access article distributed under the Creative Commons Attribution-Non Commercial Lisence (by-nc) Spain 3.0. 


\section{INTRODUCTION}

Trawling is widely held to be the human activity with the greatest impact on continental shelves all over the world (Jennings and Kaiser 1998, Thrush et al. 1998). Towed bottom fishing gears severely disturb the seabed and there are many studies highlighting their negative effects on benthic communities and habitats (e.g. Dayton et al 1995, Kaiser et al. 2000, Smith 2000). These habitats might provide critical environments for various life stages for many commercial species, i.e. spawning, recruitment and growth habitats, and are sometimes termed essential fish habitats (EFH) (Auster and Langton 1998). Alterations to the seabed may therefore indirectly affect commercial species populations, especially for those species living in close relationship with benthos and feeding on it (de Juan et al. 2007a, Fanelli et al. 2010).

The degree of seabed alteration and potential consequences on commercial species will depend on the intensity of the fishing effort. Therefore, it is important to understand the responses of benthic ecosystems to variations in trawling intensity. Communities vary over time and space in response to natural variability (de Juan and Hewitt 2014), which can be confounded with the temporal and spatial dynamics of anthropogenic disturbance factors (Koch et al. 2009). In this context, it is essential to consider the effects of the stressors over time and space, as i) the temporal frequency of the activity might condition the ability of the systems to recover between disturbance events, ii) the spatial intensity of stressors might be linked to the existence of less disturbed areas that, through connectivity mechanisms, can contribute to the ecosystem recovery (Thrush et al. 2013, Planes et al. 2006), and iii) natural variability can influence the cumulative effects as natural oscillations of communities overlap with the stressor effects.

The effects of different levels of fishing pressure on habitats and benthic communities have been explored over spatial gradients of trawling disturbance (Thrush et al. 1998, Jennings et al. 2001, Collie et al. 2005, de Juan and Demestre 2012) and temporal closures (Smith 2000, Hiddink et al. 2006a, Demestre et al. 2008). However, the effect of the temporal dynamics of trawling fleets (i.e. differences in fishing effort intensity over time in the same fishing ground) on benthic ecosystems are still unknown and cumulative impacts of trawling activities over time probably further compromise the resilience of communities (Hinz et al. 2009).

The European Marine Strategy Framework Directive (EMSFD) established by the European Commission 2008 (EC2008/56) encourages Member States to move towards an ecosystem-based fisheries management (EBFM) in order to protect ecosystems goods and services that marine ecosystems provide. Consequently, it is important to take into account the link between habitat and commercial species in management in order to move towards an EBFM if the goals of the EMSFD are to be met. There are a number of interactions through which fishing activity may influence commercial species (the principal ones are depicted in Fig. 1):

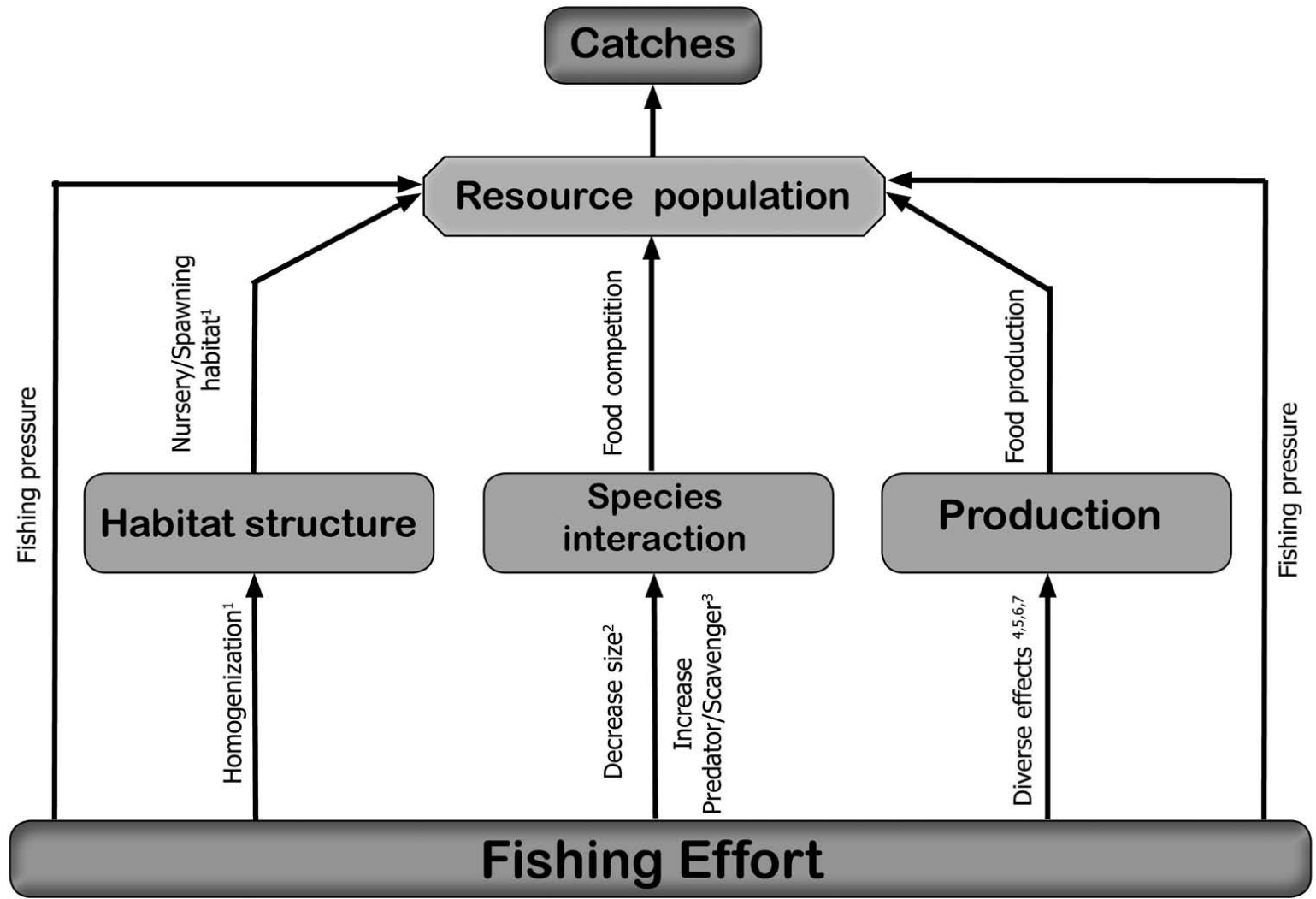

Fig. 1. - Conceptual model depicting the effects of fishing on commercial species. See the text for more details. References: ${ }^{1}$ Jennings and Kaiser 1998, ${ }^{2}$ de Juan et al. 2009, ${ }^{3}$ Rumohr and Kujawski 2000, ${ }^{4}$ Jennings et al. 2001, ${ }^{5}$ Jennings et al. 2002, ${ }^{6}$ Queirós et al. 2006, ${ }^{7}$ Hiddink et al. $2006 \mathrm{~b}$. 
i) Production: ecosystem production is represented as a food source for demersal commercial species. Production by small infauna does not seem to be affected by high fishing intensity (Jennings et al. 2002), although it can increase at moderate levels of disturbance (Jennings et al. 2001), which may benefit species feeding on small opportunistic fauna (Rijnsdorp and Vingerhoed 2001). On the other hand, production by larger infauna and epifauna would decrease in heavily trawled areas (Jennings et al. 2001, Hiddink et al. 2006b, Queirós et al. 2006), which may result in a food impoverishment for fish. Benthic carnivorous fish consume larger prey as they grow (Lukoschek and McCormick 2001), so a decrease in larger infauna might principally affect adult populations and the most economically important components of the stock (Fanelli et al. 2010). Another important food source for several demersal species, especially during the juvenile phase, is suprabenthos, whose abundance and biomass could also be affected by trawling (de Juan et al. 2007a, Fanelli et al. 2011).

ii) Habitat structure: important negative consequences of trawl fishing activity have also been described at the benthic habitat level. Habitat structure that provides shelter and favours the establishment of spawning and nursery habitats may also be altered as trawling activity is known to homogenize habitat structure (Jennings and Kaiser 1998, Thrush et al. 2001).

iii) Species interactions: changes observed in trawled areas, such as changes in epifaunal composition, might also affect commercial species as some epifaunal species compete with commercial fish for food. The epifaunal size decrease caused by trawling (de Juan et al. 2007b) might actually benefit commercial species by releasing them from large potential competitors, but the increase in predator and scavenging species (Rumohr and Kujawski 2000) could increase the food competition.

Current management strategies of the Mediterranean trawl fisheries imply effort limitation (temporal and spatial closed areas, engine power limitation, licence controls, etc.) and technical measures (minimum landing sizes, mesh size, etc.) (Caddy 1993, Smith 2000, Lleonart and Maynou 2003). All these measures focus mainly on the commercial species and are far from an integrated ecosystem approach.

Mediterranean trawl fisheries are characterized by seasonal dynamics which are mainly driven by the life cycle of the main target species (Martín et al. 1999, 2014). These characteristics, added to implementation of a closed season for many fleets as a management measure, leads to a pattern of uneven fishing effort over the year.

One of the main demersal commercial species in the study area, a trawl fishing ground in the northwestern Mediterranean, is red mullet (Mullus barbatus), which constitutes an average of $7.2 \%$ of the total catches and $7.9 \%$ of the total income. Although these may seem low figures, it is important to take into account the multispecies nature of Mediterranean trawl fisheries, with typically fewer than five species exceeding 5\% of the total catch (Sánchez et al. 2004, Martín et al. 2014). Red mullet is a species closely linked to benthic ecosystems with a well-known biology and life cycle (Demestre et al. 1997, 2000). The study area is part of a nursery ground for red mullet, as muddy sediment and depth around 15-60 m constitute the typical characteristics for this species juvenile habitat (Lombarte et al. 2000, Fiorentino et al. 2004). Likewise, the deepest zones of the study area, 50-80 m, constitute part of a reproductive habitat for this species (Machias and Labropoulou 2002, Fiorentino et al. 2004).

In the study area, fishing effects on benthic communities were assessed by characterizing it as a chronically impacted seabed (de Juan et al. 2007b). Moreover, analysis of a two-month closed period in this area revealed changes in abundance of some epifaunal mobile species (Demestre et al. 2008). In the present study, we increased our current knowledge by evaluating ecosystem responses to seasonal dynamics of trawling activities, having an unfished site as reference and the potential consequences on the exploited red mullet.

With the aim of advancing on EBFM approaches, taking into account all the effects depicted in Figure 1 and the estimations of fishing effort, the goal of the present work is to link changes in benthic functional structure with indirect effects on red mullet population under the following assumptions:

i) changes in benthic production will affect red mullet's food provision;

ii) homogenization of habitat structure affects both nursery and spawning habitat for red mullet's, and

iii) changes in epifaunal assemblage composition affect interspecific competition between epifaunal species and red mullet.

\section{MATERIALS AND METHODS}

\section{Characteristics of the study area}

The study was conducted on a muddy fishing ground located in the northwestern Mediterranean. This fishing ground spreads over $400 \mathrm{~km}^{2}$ in a depth range between 30 and $80 \mathrm{~m}$, and the study area covers a depth range of 40-60 m (Fig. 2). Within this study area, samples were taken from a fished site and from a control site that had remained undisturbed for 20 years due to the presence of the remains of an oil platform (Fig. 2) (see de Juan et al. 2007b for details). The fishing ground was operated by Sant Carles de la Ràpita trawling fleet that, with 69 vessels, is the most important trawling fleet in the Catalonia region (northeast Spain). This fleet showed variable activity throughout the year: fishing effort was high during autumn and winter, low in spring and at the beginning of summer and observed a closed season during July and August. Data on fishing effort was obtained from St. Carles de la Ràpita fishermen's association (see Demestre et al., 2008 for further details). Several abiotic characteristics of the area were measured during the benthic sampling, which was timed to cover seasonal pattern of fishing effort (Table 1). The mud sediment content was almost $100 \%$ over the whole study period and the temporal variability was not significant, which characterizes the area as a muddy habitat. 


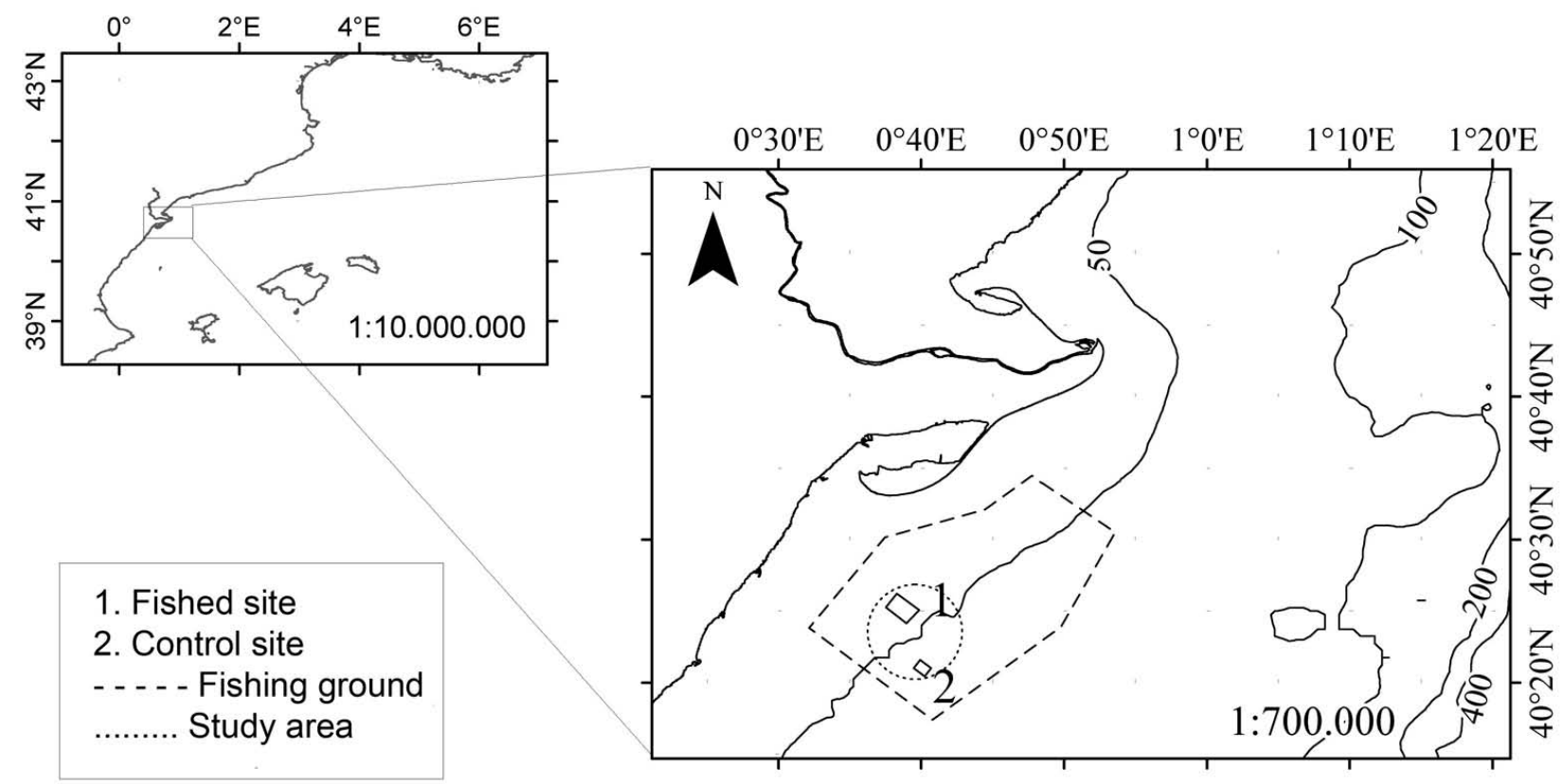

Fig. 2. - Location of the study area in the Catalan Sea off the Ebro Delta (northwestern Mediterranean).

Table 1. - Study area characterization over the sampling cruises. C, Control site; F, Fished site; \%OM, organic matter percentage; \%Mud, mud percentage on sediment; D50, mean grain size.

\begin{tabular}{|c|c|c|c|c|c|c|c|c|c|c|c|c|c|c|}
\hline \multirow{2}{*}{$\begin{array}{l}\text { Cruise } \\
\text { Site }\end{array}$} & \multicolumn{2}{|c|}{$\begin{array}{c}27 \text { to } 30 \\
\text { June } 2003\end{array}$} & \multicolumn{2}{|c|}{$\begin{array}{c}14 \text { to } 17 \\
\text { July } 2003\end{array}$} & \multicolumn{2}{|c|}{$\begin{array}{c}28 \text { to } 31 \\
\text { July } 2003\end{array}$} & \multicolumn{2}{|c|}{$\begin{array}{c}19 \text { to } 22 \\
\text { August } 2003\end{array}$} & \multicolumn{2}{|c|}{$\begin{array}{c}26 \text { to } 29 \\
\text { September } 2003\end{array}$} & \multicolumn{2}{|c|}{$\begin{array}{c}17 \text { to } 17 \\
\text { November } 2003\end{array}$} & \multicolumn{2}{|c|}{$\begin{array}{c}18 \text { to } 21 \\
\text { June } 2004\end{array}$} \\
\hline & $\mathrm{C}$ & $\mathrm{F}$ & $\mathrm{C}$ & $\mathrm{F}$ & $\mathrm{C}$ & $\mathrm{F}$ & $\mathrm{C}$ & $\mathrm{F}$ & $\mathrm{C}$ & F & $\mathrm{C}$ & F & $\mathrm{C}$ & $\mathrm{F}$ \\
\hline Turbidity (mg/l) & 1.48 & 2.38 & 1.65 & 1.37 & 1.25 & 2.66 & 1.13 & 1.72 & 4.57 & 5.76 & 3.27 & 8.11 & 1.89 & 2.88 \\
\hline$\% \mathrm{OM}$ & 0.55 & 0.59 & 0.48 & 0.59 & 0.54 & 0.64 & 0.63 & 0.70 & 0.61 & 0.68 & 0.51 & 0.63 & 0.52 & 0.61 \\
\hline$\%$ Mud & 99.5 & 99.59 & 99.48 & 99.46 & 99.23 & 99.52 & 99.29 & 99.47 & 99.38 & 99.43 & 99.33 & 99.5 & 99.33 & 99.51 \\
\hline D50 (um) & 2.65 & 4.53 & 2.73 & 4.58 & 2.68 & 4.41 & 2.67 & 4.55 & 2.82 & 4.78 & 2.75 & 4.82 & 2.75 & 4.67 \\
\hline Effort level & - & Low & - & Closed & - & Closed & -2.07 & Closed & - & High & - & High & - & Low \\
\hline
\end{tabular}

\section{Collection and processing of samples}

Samples of epifauna and infauna were collected during seven experimental cruises. Epifauna was collected with a surface dredge, similar to a $2 \mathrm{~m}$ beamtrawl with a $1-\mathrm{cm}$ cod-end, and infauna with a $0.1-\mathrm{m}^{2}$ Van Veen grab. On each cruise, a total of three epifaunal and five infaunal replicates were randomly collected at both fished and control sites. To collect the minimum sample size, estimated from species accumulation curves, the surface dredge was towed for approximately 15 minutes for each replicate and five grabs were collected per replicate. Epifaunal and infaunal organisms were identified to the lowest possible taxonomical level, generally species for epifauna and genera for infauna, and counted (see de Juan et al. 2007b for details).

\section{Data on landings and income}

Data on landings and income from 2000 to 2011 were obtained from records from the local fish auction that takes place upon the arrival of vessels at port (data source: fishing statistics elaborated by the Fisheries Department of the Catalan government). Data were available on daily landings by species (weight and income) for each fishing vessel.

\section{Trait classification to characterize benthic com- munities}

Eleven biological traits covering aspects of the benthic organisms' morphology, feeding patterns and life histories were selected to represent benthic community. The biological trait approach (BTA) allows community structure and functionality to be better represented in order to link them to the ecosystem services that the community can provide. In our case, a benthic ecosystem from a fishing ground, one of the main ecosystem services that this community provides is food production.

These 11 traits were broken down into categories. For example, feeding type was separated into the categories deposit feeder, filter/suspension feeder, opportunist/scavenger and predator (Table 2). The trait "age at sexual maturity" was treated differently for infauna and epifauna data due to the different life histories of these two groups, with most of the infauna taxa reaching the sexual maturity before a year time and epifauna species maturing later. To reduce the task to a manageable size, the data sets were reduced. For the infaunal assemblage, 25 of 147 taxa were used, comprising the species that contributed $80 \%$ of the total abundance plus those that, though not among the most abundant 
Table 2. - Biological traits and categories used to describe functional components of benthic communities. Categories used in (i) infaunal and (e) epifaunal analyses

\begin{tabular}{|c|c|}
\hline Trait & Categories \\
\hline \multirow[t]{4}{*}{ Feeding behaviour } & Deposit feeders \\
\hline & Filter/suspension feeders \\
\hline & Opportunistic/scavengers \\
\hline & Predators \\
\hline \multirow[t]{6}{*}{ Food type } & Invertebrates \\
\hline & Carrion \\
\hline & Detritus \\
\hline & Plankton \\
\hline & Microorganisms \\
\hline & Nekton \\
\hline \multirow[t]{3}{*}{ Fragility } & Fragile \\
\hline & Intermediate \\
\hline & Robust \\
\hline \multirow[t]{3}{*}{ Living habit } & Tube dweller \\
\hline & Permanent burrow dweller \\
\hline & Free-living \\
\hline \multirow[t]{5}{*}{ Size } & Very small $<1 \mathrm{~cm}$ \\
\hline & Small $1-2 \mathrm{~cm}$ \\
\hline & Small-medium 3-10 cm \\
\hline & Medium $11-20 \mathrm{~cm}$ \\
\hline & Medium-large $21-50 \mathrm{~cm}$ \\
\hline \multirow[t]{3}{*}{ Flexibility } & None $<10$ degrees \\
\hline & Low $10-15$ degrees \\
\hline & High $>45$ degrees \\
\hline \multirow[t]{4}{*}{ Life span } & $<1 \mathrm{y}$ \\
\hline & $1-2 y$ \\
\hline & $3-5 y$ \\
\hline & $>5 \mathrm{y}$ \\
\hline \multirow[t]{2}{*}{ Age at sexual maturity } & $<1$ y (i)/ 1 y (e) \\
\hline & $\geq 1 \mathrm{y}(\mathrm{i}) />1 \mathrm{y}(\mathrm{e})$ \\
\hline \multirow{4}{*}{ Adult movement } & Sessile \\
\hline & Crawl \\
\hline & Swim \\
\hline & Burrow \\
\hline \multirow[t]{4}{*}{ Reproduction frequency } & Continuous \\
\hline & 1 reproductive event per year \\
\hline & 2 or more reproductive events per year \\
\hline & Less than annual \\
\hline \multirow[t]{3}{*}{ Type of larvae } & Direct development \\
\hline & Short planktonic (<1 week) \\
\hline & Long planktonic ( $>1$ week) \\
\hline
\end{tabular}

species, were continuously present in three of the five replicates either at fished or control sites over the study period. The epifaunal data set was reduced to 17 of 96 species, which accounted for $95 \%$ of the total abundance and met the frequency of occurrence criteria.

Each taxon in the database was scored for its affinity to each trait category using a scale of $0-3(0=$ no affinity to $3=$ high affinity). The score was given using the 'fuzzy scoring' method, which allowed the taxa to exhibit more than one category of a given trait as long as the total score per trait was 3 (Bremner et al., 2003). This assignment was based on published accounts of the biology of each species and information codified in the BIOTIC database maintained by the Marine Biological Association UK (http://www.marlin.ac.uk/ biotic/). This source of information was complemented with a literature review for potential regional differences, i.e. studies conducted in the Mediterranean. When information was not available at the species level we used data based on accounts of other members of the genera or, rarely, family (only in $7.6 \%$ of cases for infauna and $3.2 \%$ for epifauna). When no information on a particular trait was available for a taxon, zero values were entered for each category and the taxon did not contribute to the calculation of trait weightings.
The frequency of each trait category in the dataset was calculated by weighting the category scores by the abundance (number of individuals per $\mathrm{m}^{2}$ ) of each taxon exhibiting that category (Charvet et al. 1998). This resulted in a sample by trait table that showed the abundance of biological traits at each station over the study period.

\section{Statistical analysis}

Similarity between each pair of samples was calculated using the Bray-Curtis index after a square root transformation of the data to reduce the influence of dominant traits/species. A PERMANOVA analysis was used to test for significant differences between sites (control and fished as fixed factors) and time (fishing effort periods, i.e. before, during and after closure, as fixed factor). The trait data were further analysed with the SIMPER routine to determine which traits accounted for the significant dissimilarities identified by PERMANOVA. Then, the most important traits highlighted by SIMPER (traits showing ratio of dissimilarity to standard deviation [diss/sd] $>1.5$ and being among the ones summing $50 \%$ of cumulative contribution to dissimilarity) were selected for univariate analyses. When traits had a normal distribution and homogeneity of variances, a two-way ANOVA was performed to test for the factors treatment and effort period. If traits were not normally distributed (even after log transformation), a Kruskall-Wallis test was performed instead. All the multivariate analyses were carried out using the PRIMER6 \& PERMANOVA statistical package (Anderson et al. 2008). Univariate analyses were performed using the R program, v.2.11.0.

\section{RESULTS}

\section{Landings and fleet dynamics in the study area}

Figure 3 shows the percentage of mantis shrimp (Squilla mantis), hake (Merluccius merluccius) and red mullet (Mullus barbatus) landings and income with respect to the total landings and income in the study area. The importance of these three species remained consistent over the years, representing around $25 \%$ of the total landings and income. The "other" percentage comprises on average 53 species, most of them accounting for less than $5 \%$ of the total catches and only sporadically (e.g. in one or two years of the data series) more than $5 \%$.

Despite an overall decrease since 2007, red mullet landings consistently followed the same trend, with a peak of catches in September/October (the recruitment months for this species), which accounted for almost $20 \%$ of the total landings (Fig. 4A, B). Figure $4 \mathrm{C}$ shows how this peak in red mullet catches coincided with the high effort period. However, red mullet landings dropped sharply in late autumn (November) whereas the decreasing trend of fishing effort was smoother as mantis shrimp landings were maintained over the winter (Fig. 4C). This figure shows how fleet dynamics followed red mullet population, as the high- 


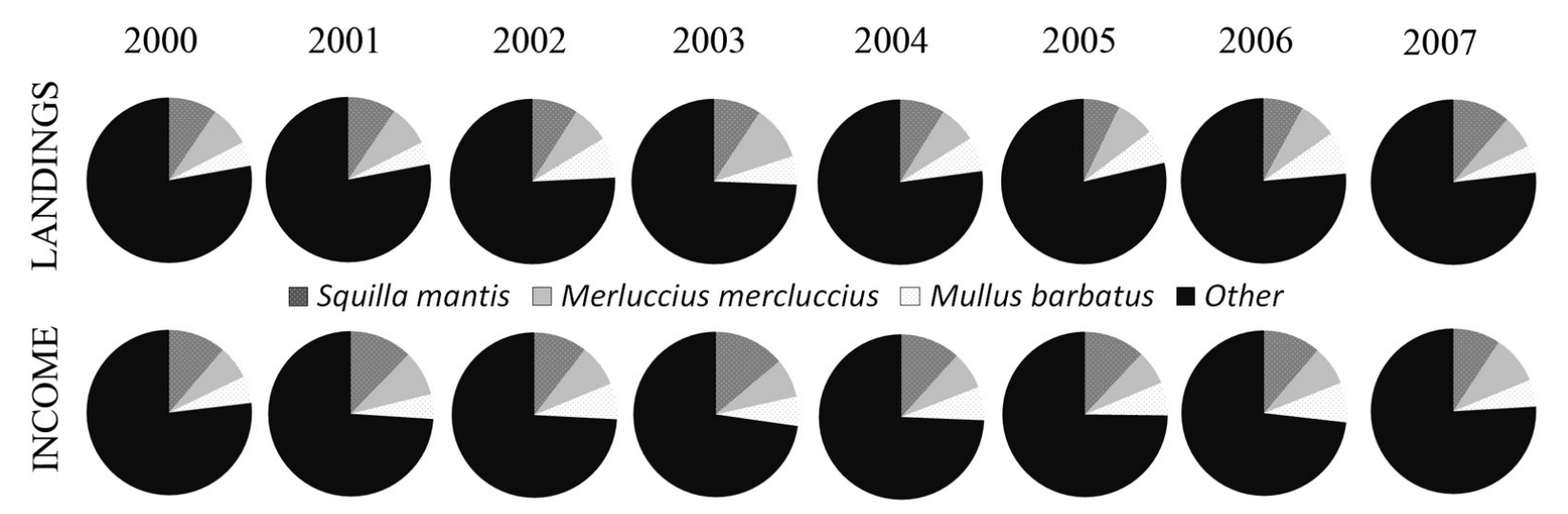

Fig. 3. - Percentage of landings and income for the main target species of the Sant Carles de la Ràpita trawling fleet.
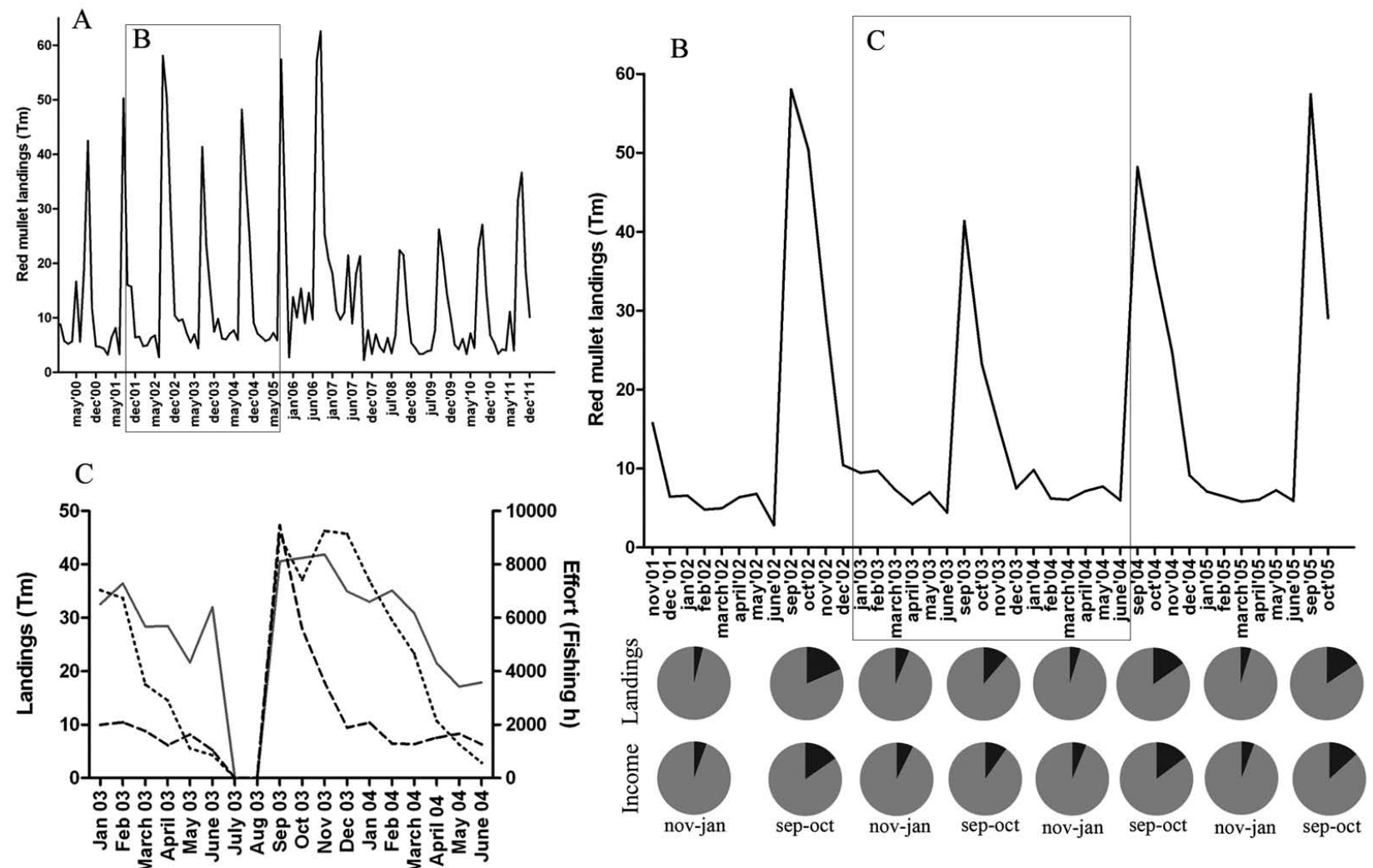

Fig. 4. - A) Evolution of red mullet catches over the years. B) Zoom from November 2001 to October 2005. Pie charts show the percentage of landings and income of red mullet (black area) with respect to total landings and income, respectively (grey area). C) Landings of Mullus barbatus (stripped line) and Squilla mantis (dotted line), and fishing effort (grey continuous line) over the study period (2003-2004).

est landings and effort occurred just after the closed season, when the trawling fleet gathered on this fishing ground to fish red mullet recruits (Demestre et al. 1997, Martín et al. 1999).

\section{Functional changes in the benthic communities}

PERMANOVA analyses highlighted significant differences for both infauna and epifauna between sites (control vs. fished) and time (different effort regimes), and site:time interaction for infauna (Table 3). Pairwise tests performed for infauna within fished sites showed significant differences between before closure and the closed season $(\mathrm{p}<0.01)$ and between before closure and
Table 3. - Infauna and epifauna PERMANOVA results for the fixed factors time and site. Significant p-values are highlighted in bold.

\begin{tabular}{lcccc}
\hline INFAUNA & df & MS & Pseudo F & p-value \\
\hline Time & 2 & 158.56 & 3.87 & $\mathbf{0 . 0 0 8}$ \\
Site & 1 & 1199.40 & 29.33 & $\mathbf{0 . 0 0 1}$ \\
Time:site & 2 & 246.35 & 6.02 & $\mathbf{0 . 0 0 3}$ \\
\hline EPIFAUNA & df & & Pseudo F & p-value \\
\hline Time & 2 & 460.56 & 5.70 & $\mathbf{0 . 0 0 2}$ \\
Site & 1 & 474.93 & 5.88 & $\mathbf{0 . 0 0 6}$ \\
Time:site & 2 & 83.05 & 1.03 & 0.354 \\
\hline
\end{tabular}

after closure periods $(\mathrm{p}<0.05)$. Furthermore, differences between times for epifauna were independent of the site, and pairwise tests performed across all samples 
Table 4. - Results of SIMPER analysis for infaunal trait abundance, comparing fished (Ab. Fished) and control (Ab. Control) sites. Fished vs control analysis was based on the whole data set, whereas effort regime analysis was based only on fished site samples. Cut-off to traits list applied at $50 \%$ of cumulative contribution to dissimilarity (Cum. Contrib.\%); traits with a ratio of dissimilarity to standard deviation (diss/sd) $>1.5$ are highlighted in bold.

\begin{tabular}{|c|c|c|c|c|c|}
\hline \multicolumn{6}{|c|}{ FISHED vs CONTROL (Average dissimilarity=12.64) } \\
\hline Traits & Ab. Fished & Ab. Control & Diss/sd & Contrib \% & Cum. Contrib \% \\
\hline$<1$ y (sex. mat) & 24.29 & 36.98 & 1.61 & 5.44 & 5.44 \\
\hline$<1$ y (life span) & 24.05 & 34.90 & 1.50 & 4.77 & 10.21 \\
\hline High flexibility & 41.92 & 47.32 & 1.38 & 4.31 & 14.52 \\
\hline Direct development & 32.34 & 39.36 & 1.45 & 4.15 & 18.67 \\
\hline Medium-large & 21.47 & 12.13 & 2.90 & 4.09 & 22.76 \\
\hline Continuous reproduction & 25.73 & 31.67 & 1.46 & 3.96 & 26.69 \\
\hline Tube dweller & 18.15 & 26.10 & 1.50 & 3.62 & 30.31 \\
\hline Permanent burrow dweller & 24.25 & 31.70 & 1.54 & 3.49 & 33.82 \\
\hline Detritus & 41.44 & 46.80 & 1.38 & 3.51 & 37.30 \\
\hline Filter feeder & 20.47 & 27.95 & 1.51 & 3.45 & 40.75 \\
\hline Small size & 21.33 & 28.89 & 1.51 & 3.28 & 44.03 \\
\hline Burrow & 44.44 & 48.03 & 1.33 & 3.25 & 47.28 \\
\hline Small-medium size & 31.28 & 35.20 & 1.40 & 3.24 & 50.51 \\
\hline \multicolumn{6}{|c|}{ BEFORE vs CLOSED (Average dissimilarity=10.03) } \\
\hline Traits & Ab. Before & Ab. Closed & Diss/sd & Contrib \% & Cum. Contrib \% \\
\hline High flexibility & 40.13 & 45.89 & 1.54 & 4.29 & 4.29 \\
\hline Intermediate fragility & 40.88 & 46.93 & 1.56 & 4.18 & 8.47 \\
\hline$<1$ y (sex. mat.) & 21.93 & 28.21 & 1.57 & 3.86 & 12.33 \\
\hline Burrow & 42.51 & 46.73 & 1.43 & 3.85 & 16.18 \\
\hline 1 repr. event/year & 35.39 & 41.18 & 1.46 & 3.72 & 19.90 \\
\hline Direct development & 30.35 & 35.67 & 1.42 & 3.69 & 23.59 \\
\hline Detritus & 39.49 & 43.93 & 1.40 & 3.61 & 27.20 \\
\hline$<1$ y (life span) & 22.42 & 27.92 & 1.41 & 3.52 & 30.72 \\
\hline Deposit feeder & 37.95 & 42.12 & 1.40 & 3.33 & 34.04 \\
\hline $2+$ repr. events/y & 3.37 & 8.94 & 1.76 & 3.26 & 37.30 \\
\hline Filter feeder & 17.72 & 23.27 & 1.70 & 3.15 & 40.45 \\
\hline Free-living & 33.90 & 37.92 & 1.47 & 3.14 & 43.60 \\
\hline Small-medium size & 30.61 & 33.56 & 1.43 & 3.07 & 46.66 \\
\hline very small size & 18.38 & 22.17 & 1.08 & 3.03 & 49.69 \\
\hline \multicolumn{6}{|c|}{ BEFORE vs AFTER (Average dissimilarity=8.65) } \\
\hline Traits & Ab. Before & Ab. After & Diss/sd & Contrib \% & Cum. Contrib \% \\
\hline High flexibility & 40.13 & 45.97 & 1.46 & 4.62 & 4.62 \\
\hline Intermediate fragility & 40.88 & 46.56 & 1.43 & 4.12 & 8.73 \\
\hline Burrow & 42.51 & 46.61 & 1.44 & 3.86 & 12.59 \\
\hline Direct development & 30.35 & 35.28 & 1.44 & 3.84 & 16.43 \\
\hline Detritus & 39.49 & 43.83 & 1.42 & 3.81 & 20.23 \\
\hline small-medium size & 30.61 & 34.40 & 1.47 & 3.70 & 23.93 \\
\hline Crawl & 9.56 & 15.01 & 1.78 & 3.66 & 27.59 \\
\hline Deposit feeder & 37.95 & 42.40 & 1.40 & 3.61 & 31.20 \\
\hline $1 \mathrm{repr}$. event/y & 35.39 & 40.27 & 1.48 & 3.48 & 34.68 \\
\hline <1 y (sex. mat.) & 21.93 & 25.81 & 1.37 & 3.34 & 38.02 \\
\hline Filter feeder & 17.72 & 22.52 & 1.56 & 3.27 & 41.29 \\
\hline Continuous reproduction & 25.00 & 28.18 & 1.39 & 2.97 & 44.26 \\
\hline Long planktonic & 16.69 & 20.28 & 1.44 & 2.88 & 47.15 \\
\hline Free-living & 33.90 & 37.53 & 1.38 & 2.86 & 50.01 \\
\hline
\end{tabular}

showed significant differences between before closure and after closure periods $(\mathrm{p}<0.01)$ and between closed season and after closure periods $(\mathrm{p}<0.01)$. Ordination of samples in a multi-dimensional scaling plot did not reflect any clear pattern and was not included.

SIMPER analysis for infaunal samples highlighted the traits "sexual maturity at less than 1 year" and "life span of less than 1 year" as the principal traits driving the differences between fished and control sites, both being more abundant in the control site. "Mediumlarge size" (more prevalent at the fished site) was also an important trait discriminating sites (Table 4).

SIMPER analysis performed only for infaunal fished samples revealed "high flexibility", "intermediate fragility" and " $<1$ y sexual maturity" as the main traits driving the differences between before closure and closed season periods, although they showed relatively low diss/sd (Table 4). All these traits were more abundant during the closed season. "Filter feeding" and " 2 or more reproductive events per year", with relatively high diss/sd and also more abundant during the closed season, were important in discriminating between these two periods. Finally, "crawl" and "filter feeding" were the traits making the difference between the before closure and after closure period, both being more abundant in the latest (Table 4).

The SIMPER routine for epifaunal samples highlighted the traits "medium", ">5 y life span", "low flexibility" and "medium-large" as the most important traits driving the differences between control and fished sites, all of them being more abundant at the control site (Table 5). As the PERMANOVA test showed no significant interaction between site and time for epifaunal samples (Table 3), a SIMPER test based on the whole data set was performed to identify the traits driving the differences between effort regimes. This analysis highlighted "no flexibility", "deposit feeder", "permanent burrow dweller", "burrow" and "detritus"as the traits 
60 - A. Muntadas et al.

Table 5. Results of SIMPER analysis for epifaunal traits abundance, comparing fished (Ab. Fished) and control (Ab. Control) sites. All analyses were based on the whole data set. Cut-off to traits list applied at 50\% of cumulative contribution to dissimilarity (Contrib.\%); traits with a ratio of dissimilarity to standard deviation (diss/sd) $>1.5$ are highlighted in bold.

\begin{tabular}{|c|c|c|c|c|c|}
\hline \multicolumn{6}{|c|}{ FISHED vs CONTROL (Average dissimilarity=12.98) } \\
\hline Traits & Ab. Fished & Ab. Control & Diss/sd & Contrib \% & Cum. Contrib \% \\
\hline High flexibility & 15.10 & 13.11 & 1.26 & 4.43 & 4.43 \\
\hline Medium size & 1.09 & 5.00 & 2.37 & 4.42 & 8.85 \\
\hline 3-5 y (life span) & 15.13 & 13.81 & 1.24 & 4.29 & 13.14 \\
\hline$>1$ y (sex.mat) & 15.40 & 15.37 & 1.25 & 4.18 & 17.32 \\
\hline Crawl & 17.48 & 15.86 & 1.25 & 3.93 & 21.25 \\
\hline Intermediate fragility & 19.10 & 19.49 & 1.36 & 3.81 & 25.07 \\
\hline$>5$ y (life span) & 5.59 & 8.83 & 1.68 & 3.8 & 28.86 \\
\hline $1 \mathrm{repr}$. event/year & 20.05 & 20.37 & 1.35 & 3.73 & 32.60 \\
\hline Long planktonic & 19.42 & 19.61 & 1.37 & 3.71 & 36.31 \\
\hline Small-medium size & 19.77 & 18.55 & 1.29 & 3.69 & 40.00 \\
\hline Free-living & 18.06 & 18.47 & 1.43 & 3.67 & 43.67 \\
\hline Low flexibility & 5.41 & 8.22 & 1.66 & 3.42 & 47.09 \\
\hline Medium-large size & 3.80 & 6.57 & 1.72 & 3.23 & 50.32 \\
\hline \multicolumn{6}{|c|}{ BEFORE vs AFTER (Average dissimilarity = 16.33) } \\
\hline Traits & Ab. Before & Ab. After & Diss/sd & Contrib \% & Cum. Contrib \% \\
\hline No flexibility & 15.46 & 9.15 & 2.16 & 6.16 & 6.16 \\
\hline 3-5 y (life span) & 13.01 & 15.00 & 1.36 & 4.71 & 10.87 \\
\hline$>1$ y (sex. mat) & 14.10 & 15.53 & 1.37 & 4.68 & 15.54 \\
\hline High $>45$ & 12.91 & 14.61 & 1.40 & 4.45 & 19.99 \\
\hline Intermediate fragility & 19.96 & 17.43 & 1.45 & 3.97 & 23.97 \\
\hline Deposit feeder & 9.99 & 6.03 & 2.11 & 3.95 & 27.92 \\
\hline Permanent burrow dweller & 11.30 & 7.35 & 1.68 & 3.94 & 31.86 \\
\hline 1 repr. event/y & 20.98 & 17.93 & 1.44 & 3.94 & 35.80 \\
\hline Long planktonic & 20.27 & 17.40 & 1.43 & 3.92 & 39.72 \\
\hline Burrow & 9.93 & 5.90 & 2.06 & 3.9 & 43.62 \\
\hline Detritus & 10.30 & 6.36 & 2.03 & 3.89 & 47.51 \\
\hline Small-medium size & 20.01 & 16.99 & 1.35 & 3.72 & 51.23 \\
\hline \multicolumn{6}{|c|}{ CLOSED vs AFTER (Average dissimilarity = 13.83) } \\
\hline Traits & Ab. Close & Ab. After & Diss/sd & Contrib \% & Cum. Contrib \% \\
\hline No flexibility & 14.48 & 9.15 & 2.10 & 6.00 & 6.00 \\
\hline $1 \mathrm{repr}$. event $/ \mathrm{y}$ & 21.21 & 17.93 & 1.44 & 4.40 & 10.40 \\
\hline Long planktonic & 20.43 & 17.40 & 1.42 & 4.25 & 14.65 \\
\hline Small-medium size & 20.04 & 16.99 & 1.44 & 4.16 & 18.80 \\
\hline Permanent burrow dweller & 10.92 & 7.35 & 1.82 & 4.11 & 22.91 \\
\hline Intermediate fragility & 20.10 & 17.43 & 1.40 & 4.08 & 27.00 \\
\hline Deposit feeder & 9.54 & 6.03 & 2.07 & 4.01 & 31.00 \\
\hline Detritus & 9.81 & 6.36 & 2.08 & 3.99 & 34.99 \\
\hline Burrow & 9.33 & 5.90 & 2.08 & 3.86 & 38.85 \\
\hline Fragile & 7.12 & 3.94 & 1.80 & 3.84 & 42.69 \\
\hline Free-living & 19.07 & 16.85 & 1.39 & 3.61 & 46.29 \\
\hline Crawl & 17.27 & 15.84 & 1.42 & 3.29 & 49.58 \\
\hline
\end{tabular}

Filter feeder

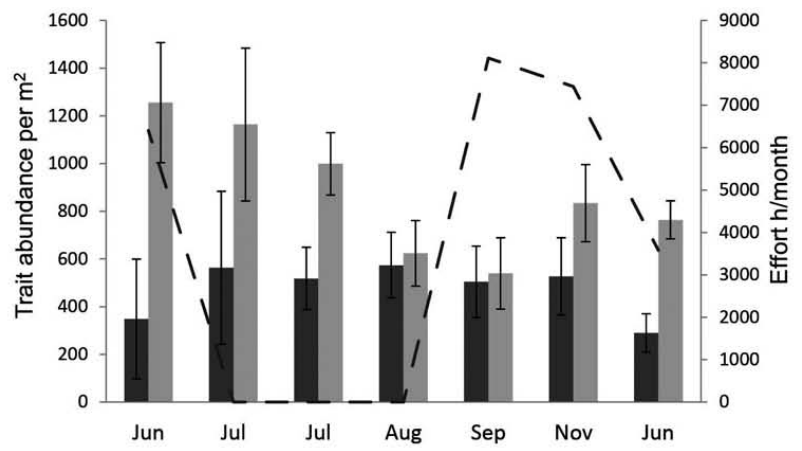

2 or more reproductive events per year

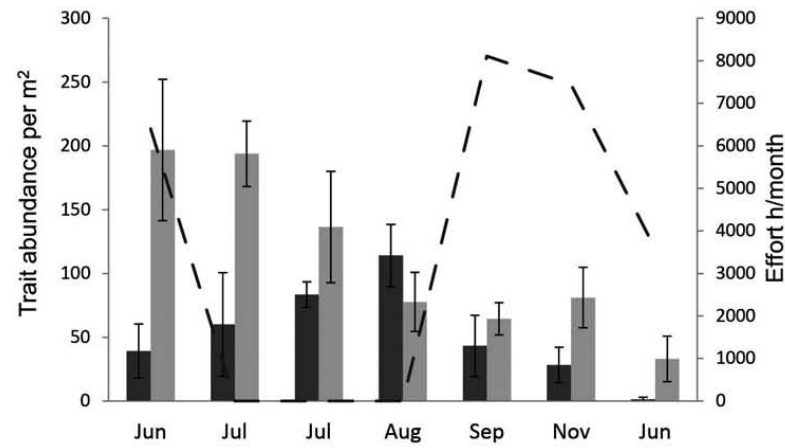

Fig. 5. - Mean ( \pm se) trait abundance of infauna at fished (black bars) and control sites (grey bars). Dashed line shows fishing effort. June corresponds to before closure period, July and August to closed season and September and November to after closure period.

discriminating between the before and after closure periods and between the closed season and after closure periods. All these traits were more abundant in the before closure period and the closed season respectively. "Fragile", more abundant during the closed season, was also found to be important in discriminating be- tween the closed season and the after closure period (Table 5).

Though these traits were highlighted by SIMPER analysis, it should be noted that average dissimilarities among fishing effort periods were low (10.03 and 8.65 for infauna and 16.33 and 13.83 for epifauna) (Tables 
Deposit feeder

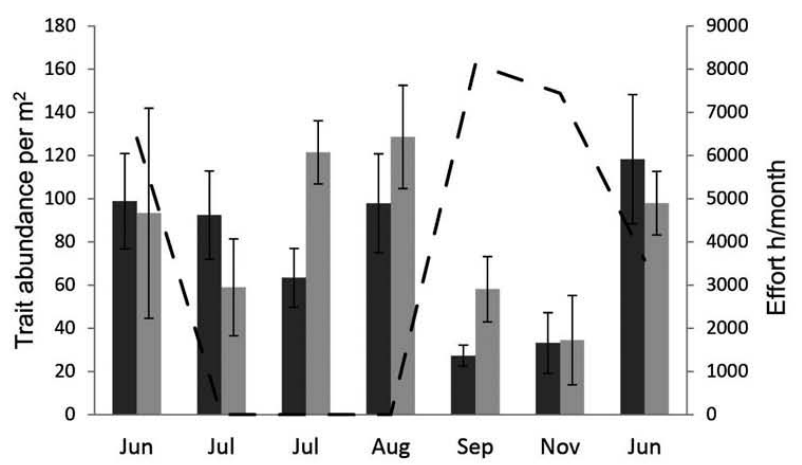

Fragile

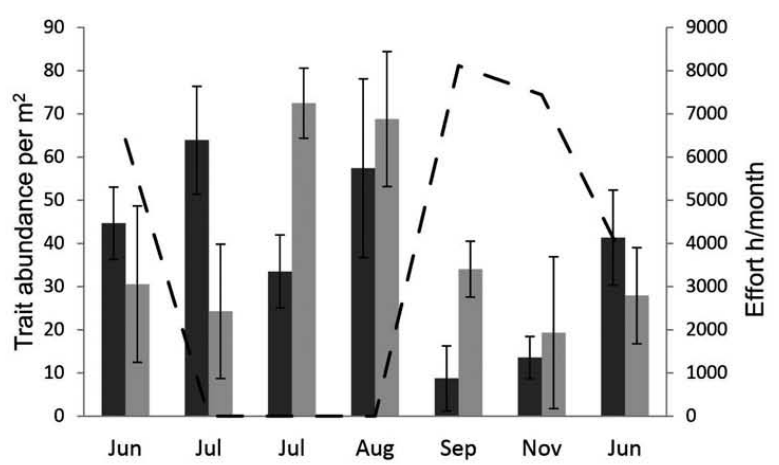

Fig. 6. Mean $( \pm$ SE) trait abundance of epifauna at fished (black bars) and control sites (grey bars). Dashed line shows fishing effort. June corresponds to before closure period, July and August to closed season and September and November to after closure period.

Table 6. - Summary of ANOVA/Kruskal-Wallis and pairwise tests for traits highlighted by SIMPER routine (traits showing a ratio of dissimilarity to standard deviation [diss/sd] $>1.5$ and being among the $50 \%$ of total contribution). $* \mathrm{p}<0.05$, ** $\mathrm{p}<0.01$, *** $\mathrm{p}<0.0001$, ns, non-significant; $b$, before closed; $c$, closed season; $a$, after closed $^{1}$; the specific comparisons were not significant.

\begin{tabular}{lccc}
\hline Infauna & Site & Time & Site: time \\
\hline$<1$ y (life span) & $* * *$ & $\mathrm{~ns}$ & $*$ \\
$<1$ y (sex.mat) & $* * *$ & $\mathrm{~ns}$ & $*$ \\
Medium-large size & $* * *$ & $\mathrm{~ns}$ & $\mathrm{~ns}$ \\
Tube dweller & $* * *$ & $\mathrm{~ns}$ & $*$ \\
Permanent burrow dweller & $* * *$ & $\mathrm{~ns}$ & $* *$ \\
Intermediate fragility & $\mathrm{ns}$ & $*(\mathrm{c} \neq \mathrm{a}, \mathrm{b})$ & $*$ \\
High flexibility & $*$ & $\mathrm{~ns}$ & $*$ \\
Filter/suspension feeder & $* * *$ & $\mathrm{~ns}$ & $*$ \\
Crawl & $*$ & $*(\mathrm{~b} \neq \mathrm{a}, \mathrm{c})$ & $\mathrm{ns}$ \\
2+ repr. events/y & $* * *$ & $* 1$ & $*$ \\
\hline Epifauna & Site & Time & Site: time \\
\hline Deposit feeder & $\mathrm{ns}$ & $*(\mathrm{a} \neq \mathrm{b}, \mathrm{c})$ & $\mathrm{ns}$ \\
Detritus & $\mathrm{ns}$ & $*(\mathrm{a} \neq \mathrm{b}, \mathrm{c})$ & $\mathrm{ns}$ \\
Burrow & $\mathrm{ns}$ & $*(\mathrm{a} \neq \mathrm{b}, \mathrm{c})$ & $\mathrm{ns}$ \\
No flexibility & $\mathrm{ns}$ & $*(\mathrm{a} \neq \mathrm{b}, \mathrm{c})$ & $\mathrm{ns}$ \\
Permanent burrow dweller & $\mathrm{ns}$ & $* * *(\mathrm{a} \neq \mathrm{b}, \mathrm{c})$ & $\mathrm{ns}$ \\
Fragile & $\mathrm{ns}$ & $* * * a l l$ times & $\mathrm{ns}$ \\
Medium size & $* * *$ & $\mathrm{~ns}$ & $*$ \\
Medium- large size & $* * *$ & $\mathrm{~ns}$ & $*$ \\
Low flexibility & $* * *$ & $\mathrm{~ns}$ & $*$ \\
$>5$ y (life span) & $* *$ & $\mathrm{~ns}$ & $\mathrm{~ns}$ \\
\hline
\end{tabular}

4, 5). Average dissimilarities between control and fished areas were also low (12.64 for infauna and 12.98 for epifauna).

Figures 5 and 6 show the trends of two traits for infauna (Fig. 5) and epifauna (Fig. 6) over the study period. These traits were highlighted by the SIMPER routine as being important in discriminating between fishing effort periods. Infaunal "filter feeding" and "two or more reproductive events" showed a decreasing trend over the study period at the control site but, whereas for "filter feeding" there seems to be no change at the fished site, in "two or more reproductive events" there was an increasing trend until the end of the closed season and afterwards this trait abundance decreased. Fishing effort values are overlapped in the figure, showing that epifaunal "deposit feeder" and "fragile" organisms were more abundant at fished and control sites when effort was low or null, in the autumn months. Plots for other traits are not included as they showed similar trends to those in Figures 5 and 6: "Filter feeder" trend for infauna was similar to "high flexibility" and highly similar to "<1 y of life span", and" $<1$ y sexual maturity". On the other hand, the "deposit feeder" trend for epifauna was highly similar to "detritus", "burrow" and "no flexibility", and the "fragile" trend was highly similar to "permanent burrow dwelling".

Table 6 shows that differences over fishing effort periods (time) for almost all these traits were significant, confirming that they were important in discriminating between these periods. Factor time was not significant for infaunal "filter feeder" and thus all the traits show a similar trend; however, the site:time interaction was significant, suggesting an influence of fishing effort periods or seasonality on these traits' changes. Traits highlighted by SIMPER as the ones driving the differences between control and fished sites also showed significant differences for the factor site

\section{DISCUSSION}

\section{Potential effects of fishing on red mullet population caused by functional changes in benthic communi- ties}

Different fish species have different habitats requirements, which could be more or less resilient to trawling impacts (Kaiser et al. 1999). The Sant Carles de la Ràpita fishing ground, our case study, is part of a nursery habitat for red mullet (Lombarte et al. 2000, Fiorentino et al. 2004), which is one of the most important commercial fish in the study area (Sánchez et al. 2007). Moreover, this species was chosen as a case study because it is a species closely related to the benthic system, with a well-known biology and life cycle which leads to particular catch dynamics (Fig. 4A). The existence of a nursery habitat is supported by the high catches of new recruits observed after the closed season, in September-October, which constitutes a specific characteristic of this species fisheries (Martin et al. 1999). Recruitment is a critical step for most fish life cycles and decline in recruitment may have important consequences for adult commercial stock (Bundy and Fanning 2005, Caddy in press). Therefore, the protection of benthic communities and habitat structure, which provide food and shelter for young fish, is es- 


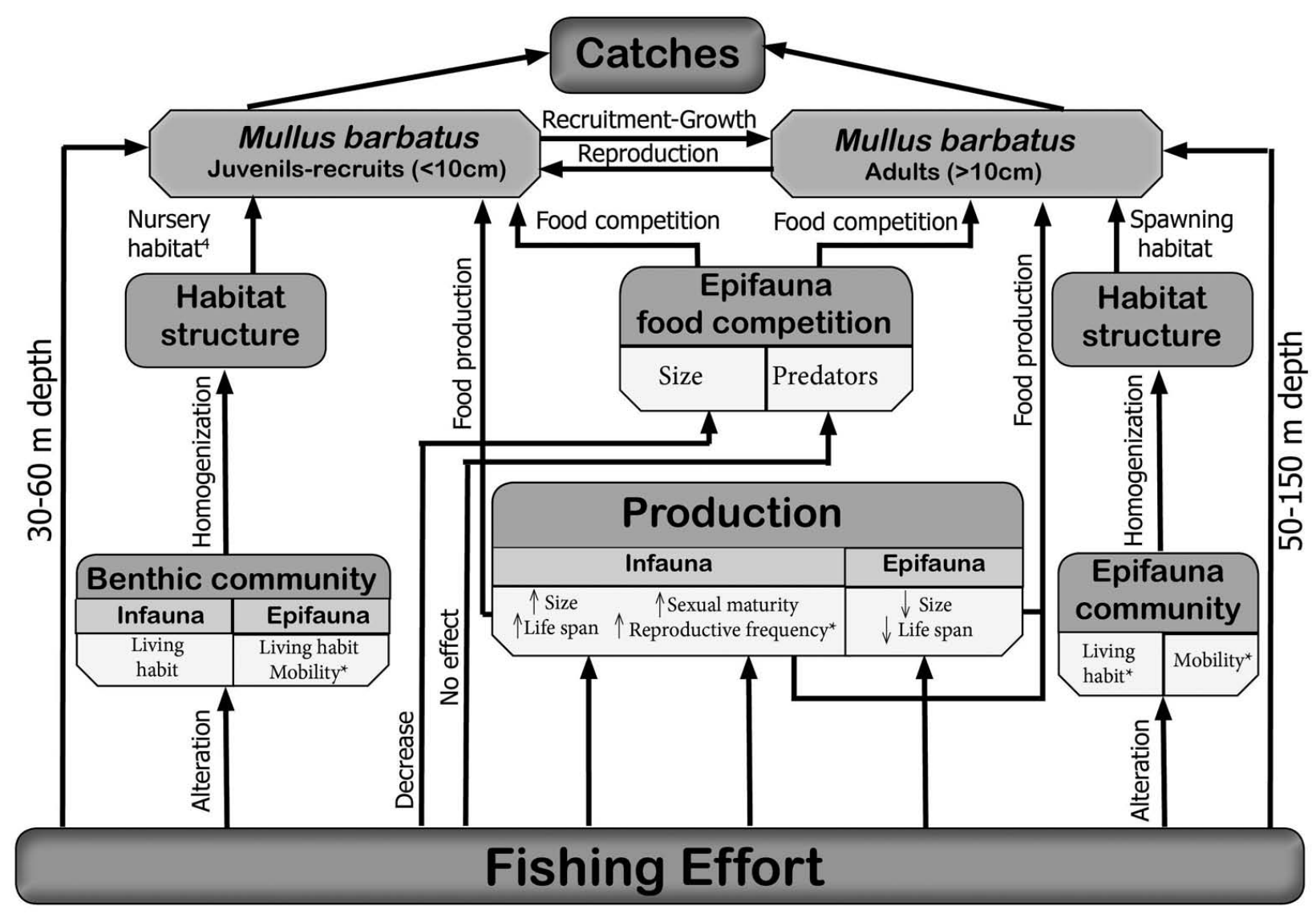

Fig. 7. Complex interactions and main potential effects of changes in benthic community due to trawling on red mullet population. $*$ Traits changing over different fishing effort regimes; the other traits showed differences between fished and control sites

sential to maintain a healthy adult stock.

As red mullet lives in a close relationship with the benthic environment for feeding, reproduction and refuge, this species might be particularly affected by the chronic alteration of benthic ecosystems (Auster and Langton 1998, Caddy in press). In this study we aimed to assess potential negative effects of trawling on red mullet due to changes on benthic functional components in the fishing ground (Fig. 7).

Regarding the food availability, small, short-lived infaunal organisms were more abundant at the control site, which might contribute to higher food production for red mullet in this site, especially for young recruits that feed on smaller prey (Machias and Labropoulou 2002). Moreover, during the closed season in summer, production of small infauna at the fished site may increase due to the higher prevalence of traits related to rapid reproduction (Fig. 7). The closed season coincides with the early phase of recruitment of red mullet (Fiorentino et al. 2008), so young red mullet recruits might benefit from higher food production in summer months. On the other hand, medium-large infaunal organisms dominated the fished site (Fig. 7), which could represent higher prey abundance for adult red mullet in the fishing ground. These results seems to contradict the current understanding of the effects of fishing on marine benthos, suggesting that communities in areas with a long history of fishing would consist mainly of small organisms (Jennings et al. 2001, Queirós et al.
2006). However, all medium-large taxa in the study area were deep burrowers that might avoid trawling disturbance (Brown et al. 2005), and also generally opportunistic-predator feeders that usually benefit from fishing activity (Frid et al. 2000).

Some of the observed trends in infaunal traits over the study period matched the fishing effort pattern, but the variability in infaunal abundance would more likely be related to seasonal patterns as the closed season in the fishing ground is too short to allow ecosystem recovery (Zajac 2003, Kaiser et al. 2006). The decreasing trend for almost all infaunal traits at the control site in summer and early autumn (closed and after closed season) could indicate a decrease in the overall infaunal abundance consistent with the temporal cycles shown by macroinfauna in the Mediterranean (Sardá et al. 1999). In contrast, the reduction of this seasonal trend at the fished site could be due to chronic fishing disturbance, which could alter the natural macroinfaunal cycles (de Juan et al. 2007b). However, this lack of trend in the fished site cannot be unequivocally linked to the fishing activities as natural processes could also play a role, resulting in an additive effect of both fishing and environmental variability (Koch et al. 2009).

In the epifaunal community, as expected and in agreement with de Juan et al. (2009), traits related to long life span and large size were more abundant at the control site (Table 5). This means that epifauna productivity (production/biomass) would be lower in the 
control area, although biomass production would be higher in this area. These large long-living organisms were fishes and large bivalves (e.g. Citharus linguatula or Acanthocardia echinata) that are not red mullet preys and, if they are predators, might compete with red mullet for prey. For example, Citharus linguatula, feeds in this area on decapoda and other small crustaceans (Juan et al. 2007a), which are potential prey for red mullet (Aguirre 2000), so these two fish partially share the trophic niche. Therefore, although adult red mullet could potentially find more food at the control site, this food would be less available due to interspecific competiveness (Fig. 7).

Regarding the habitat structure, as the control site is slightly deeper than the fished site, it might be a spawning area for red mullet. However, no traits related to habitat structure (e.g. sessile emerging epifauna) were highlighted in the analysis. In general, the whole fishing ground holds a homogenized community with a reduced habitat structure due to historical trawling disturbance in the area (de Juan et al. 2007b, 2009) (Fig. 7). Nevertheless, physical habitat is also important in creating habitat structure for recruits and spawners, and ROV images showed higher abundance of sediment structures such as ripples, mounds and pits at the control site (Demestre 2006). Changes in the trait "burrow" or "permanent burrow dwelling", which seemed to occur in similar abundance at fished and control sites over the sampled months, would not benefit red mullet spawning as these traits would destabilize the sediment with negative consequences for the creation of habitat structure (Lohrer et al. 2008). However, changes in these traits may affect bioturbation activity which may positively affect ecosystem production (Thrush and Dayton 2002, Lohrer et al. 2004) and indirectly benefit red mullet population in terms of food availability by enhancing primary production.

\section{Management considerations}

Associating demersal fish with their habitats is very critical to the definition of EFH and to correctly managing those EFH impacted by trawling activities (Kaiser et al. 1999). However, management strategies such as closed seasons are principally implemented to protect vulnerable steps of commercial species' life cycles such as spawning and recruitment, focusing only on commercial species stock and not taking into account protection of benthic communities. Short-term closed seasons, such as the one implemented in the Sant Carles de la Ràpita fishing ground, do not enable benthic community recovery between successive periods of impact, especially on stable muddy bottoms where communities might take years to recover (Kaiser et al. 2006). Furthermore, short-term closures result in a concentration of the trawl effort and landings immediately after the closed season rather than in a more equitable pattern throughout the year (Martin et al. 1999). This concentration of fishing effort is also accompanied by an increase in discards (Sánchez et al. 2007), which indicates a higher level of disturbance on benthic communities. An adequate management regu- lation should progressively increase the fleet capacity after the closed season to avoid resource depletion and the highest disturbance levels on ecosystems.

Red mullet are an important commercial species in the Mediterranean, being one of the main target species for trawling fleets (Caddy 1993, Tserpes et al. 2002). In this case, the red mullet life cycle drives the fleet dynamics, as the highest fishing effort coincides with the highest landings (Fig. 4C), which are composed mainly of red mullet recruits (Demestre et al. 1997, Martín et al. 1999). Though the red mullet population could apparently tolerate this level of exploitation due to its high turnover rate, the yield per recruit shows evidence of overexploitation (Demestre et al. 1997) and this dominance of young specimens in landings makes the stock highly vulnerable to recruitment changes (Tserpes et al. 2002). Therefore, it would be advisable to protect red mullet nursery and spawning areas. Actually, Fiorentino et al. (2008) reported an increase in the number of recruits and a wider recruitment period after a trawl ban in the Gulf of Castellammare, exemplifying that an implementation of a permanently closed area does benefit reproduction success of this species. Moreover, a benthic community in a permanent closed area will have the possibility to recover from trawling impact, which might benefit not only red mullet but also other commercial species (e.g. the structured soft-bottom community observed in the Medes Island MPA, de Juan et al. 2011).

This work shows that changes in the effort regime within a year only had limited consequences for benthic community structure, whereas changes between a non-fished control site and a fished site were clearly evident. The observed changes at the fished site might benefit adult red mullet, as their food provision will be higher due to an increase in medium-large infauna and to lower interspecific trophic competition. However, red mullet recruits will be negatively affected by functional changes caused by fishing as their food provision might overall decrease, although they could benefit from a short-term increase in food production during summer. Moreover, both adults and recruits will suffer from lack of protection of habitat structures. Thus, the overall effect of trawling on the red mullet stock, considering the high fishing pressure on recruits and the indirect negative effects caused by ecosystem disturbance, could be a decrease in the spawning stock that will worsen the recruit's stock situation.

This study highlights the idea that permanent closure areas, which would allow recovery of the benthic ecosystem, restructuring habitats and communities, might be more beneficial for commercial species and their habitats than temporary closures.

\section{ACKNOWLEDGEMENTS}

This study was funded by the EU project RESPONSE (Q5RS-2002-00787) and the COMSOM project (CTM2008-04617). We thank the participants in the "Veda" cruises and the crew of the RV Garcia del Cid for their help. Fishing effort data were provided by the Fishermen's Association of Sant Carles. Alba 
Muntadas was supported by a CSIC JAE_predoc grant cofunded by the European Social Funds and Silvia de Juan was supported by a postdoctoral mobility grant from the Spanish Ministry of Education (Programa nacional de movilidad de recursos humanos del Plan Nacional I+D+i 2008-2011). This study is the result of a stay by A. Muntadas at the University of Liverpool funded by the JAE predoc programme.

\section{REFERENCES}

Aguirre H. 2000. Aspectos Biológicos y Ecológicos del Salmonete de Fango Mullus barbatus L., 1758 y del Salmonete de Roca Mullus surmuletus L., 1758, del Mediterráneo Noroccidental. Ph.D. thesis, Tech. Univ. Catalonia, 147-213 pp.

Anderson M.J., Gorley R.N., Clarke K.R. 2008. PERMANOVA + for PRIMER: Guide to Software and Statistical Methods. The University of Auckland Press, 214 pp.

Auster P.J., Langton R.W. 1998. The effects of fishing on fish habitat. Am. Fish. Soc. Symp. 22: 150-187.

Bremner J., Rogers S., Frid C. 2003. Assessing functional diversity in marine benthic ecosystems: a comparison of approaches. Mar. Ecol. Prog. Ser. 254: 11-25. http://dx.doi.org/10.3354/meps254011

Brown E.J., Finney B., Dommiss, M., Hills S. 2005. Effects of commercial otter trawling on the physical environment of the southeastern Bering Sea. Cont. Shelf Res. 25(10): 1281-1301. http://dx.doi.org/10.1016/j.csr.2004.12.005

Bundy A., Fanning L.P. 2005. Can Atlantic cod (Gadus morhua) recover? Exploring trophic explanations for the non-recovery of the cod stock on the eastern Scotian Shelf, Canada. Can. J. Fish. Aquat. Sci. 62: 1474-1489. http://dx.doi.org/10.1139/f05-086

Caddy J.F. 1993. Some future persperctives for assessment and management of Mediterranean fisheries. Sci. Mar. 57(2-3): 121-130.

Caddy J.F. in press. Why do assessments of demersal stocks largely ignore habitat? ICES J. Mar. Sci. http://dx.doi.org/10.1093/icesjms/fss199

Charvet S., Kosmala A. Statzner B. 1998. Biomonitoring through biological traits of benthic macroinvertebrates: perspectives for a general tool in stream management. Arch. für Hydrobiol. 142(4): 415-432.

Collie J. S., Hermsen J. M., Valentine P. C. 2005. Effects of fishing on gravel habitats: assessment and recovery of benthic megafauna on Georges Bank. Am. Fish. Soc. Symp. 41: 325-343.

Dayton P.K., Thrush S.F, Agardy M.T., Hofman R.J. 1995. Environmental effects of marine fishing. Aquatic. Conserv. 5: 205-232. http://dx.doi.org/10.1002/aqc.3270050305

de Juan S., Demestre M. 2012. A Trawl Disturbance Indicator to quantify large scale fishing impact on benthic ecosystems. Ecol. Indic. 18: 183-190. http://dx.doi.org/10.1016/j.ecolind.2011.11.020

de Juan S., Hewitt J. 2014. Spatial and temporal variability in species richness in a temperate intertidal community. Ecography 37(2): 183-190. http://dx.doi.org/10.1111/j.1600-0587.2013.00048.x

de Juan S., Cartes J. E., Demestre M. 2007a. Effects of commercial trawling activities in the diet of the flat fish Citharus linguatula (Osteichthyes: Pleuronectiformes) and the starfish Astropecten irregularis (Echinodermata: Asteroidea). J. Exp. Mar. Biol. Ecol. 349(1): 152-169. http://dx.doi.org/10.1016/j.jembe.2007.05.003

de Juan S., Thrush S., Demestre M. 2007b. Functional changes as indicators of trawling disturbance on a benthic community located in a fishing ground (NW Mediterranean Sea). Mar. Ecol. Prog. Ser. 334: 117-129. http://dx.doi.org/10.3354/meps334117

de Juan S., Demestre M., Thrush S. 2009. Defining ecological indicators of trawling disturbance when everywhere that can be fished is fished: A Mediterranean case study. Mar. Policy 33 (3): 472-478 http://dx.doi.org/10.1016/j.marpol.2008.11.005

de Juan S., Demestre M., Sánchez P. 2011. Exploring the degree of trawling disturbance by the analysis of benthic communities ranging from a heavily exploited fishing ground to an undis- turbed area in the NW Mediterranean. Sci. Mar. 75(3): 507-516. http://dx.doi.org/10.3989/scimar.2011.75n3507

Demestre M. 2006. Response of benthic communities and sediment to different regimens of fishing disturbance in European coastal waters. EU Project Q5RS-2002-00787. Final Report, 639 pp.

Demestre M., Sbrana M., Alvarez F., Sánchez P. 1997. Analysis of the interaction of fishing gear in Mullus barbatus fisheries of the Western Mediterranean. J. Appl. Ichtyology 13: 49-56. http://dx.doi.org/10.1111/j.1439-0426.1997.tb00100.x

Demestre M., Sánchez P., Abelló P. 2000. Demersal fish assemblages and habitat characteristics on the continental shelf and upper slope of the North-Western Mediterranean. J. Mar. Biol. Assoc. U.K. 80: 981-988 http://dx.doi.org/10.1017/S0025315400003040

Demestre M., de Juan S., Sartor P., Ligas A. 2008. Seasonal closures as a measure of trawling effort control in two Mediterranean trawling grounds: effects on epibenthic communities. Mar. Pollut. Bull. 56(10): 1765-1773. http://dx.doi.org/10.1016/j.marpolbul.2008.06.004

European Comission 2008. Directive 2008/56/EC of the European Parliament and of the council of 17 June 2008 establishing a framework for community action in the field of marine environmental policy (Marine Strategy Framework Directive). Official Journal of the European Union, L167/19

Fanelli E., Badalamenti F., D’Anna G., Pipitone C., Romano C. 2010. Trophodynamic effects of trawling on the feeding ecology of pandora, Pagellus erythrinus, off the northern Sicily coast (Mediterranean Sea). Mar. Freshw. Res. 61(4): 408. http://dx.doi.org/10.1071/MF09049

Fanelli E., Cartes J. E., Badalamenti F., D’Anna G., Pipitone C., Azzurro E., Rumolo P., Sprovieri M. 2011. Meso-scale variability of coastal suprabenthic communities in the southern Tyrrhenian Sea (Western Mediterranean). Estuar. Coast. Shelf Sci. 91(3): 351-360. http://dx.doi.org/10.1016/j.ecss.2010.10.026

Fiorentino F., Garofalo, G., Gristina M., Gancitano, S., Norrito G. 2004. Some relevant information on the spatial distribution of demersal resources, benthic biocoenoses and fishing pressure in the Strait of Sicily. Report of the MedSudMed Expert Consultation on Spatial Distribution of Demersal Resources in the Straits of Sicily and the Influence of Environmental Factors and Fishery Characteristics. GCP/RER/010/ITA/MSM-TD-02. MedSudMed Technical Documents 2: 50-66.

Fiorentino F., Badalamenti F., D’Anna G., Garofalo G., Gianguzza P., Gristina M., Pipitone C., Rizzo P., Fortibuoni T. 2008. Changes in spawning-stock structure and recruitment pattern of red mullet, Mullus barbatus after a trawl ban in the Gulf of Castellammare (central Mediterranean Sea). ICES J. Mar. Sci. 65: $1175-1183$ http://dx.doi.org/10.1093/icesims/fsn104

Frid C.L.J., Harwood K.G., Hall S.J., Hall J.A. 2000. Long-term changes in the benthic communities on North Sea fishing grounds. ICES J. Mar. Sci. 57(5): 1303-1309. http://dx.doi.org/10.1006/jmsc.2000.0900

Hiddink J., Hutton T., Jennings S., Kaiser M. 2006a. Predicting the effects of area closures and fishing effort restrictions on the production, biomass, and species richness of benthic invertebrate communities. ICES J. Mar. Sci. 63(5): 822-830. http://dx.doi.org/10.1016/j.icesims.2006.02.006

Hiddink J. G., Jennings,S., Kaiser M. J., Queirós A. M., Duplisea D. E., Piet G. J. 2006b. Cumulative impacts of seabed trawl disturbance on benthic biomass, production, and species richness in different habitats. Can. J. Fish. Aquat. Sci. 736: 721-736. http://dx.doi.org/10.1139/f05-266

Hinz H., Prieto V., Kaiser M. J. 2009. Trawl disturbance on benthic communities: Chronic effects and experimental predictions. Ecol. Appl. 19(3): 761-773 http://dx.doi.org/10.1890/08-0351.1

Jennings S., Kaiser M. J. 1998. The effects of fishing on marine ecosystems. Adv. Mar. Biol. 34: 268-352. http://dx.doi.org/10.1016/S0065-2881(08)60212-6

Jennings S., Dinmore T.A., Duplisea D.E., Warr K.J., Lancaster J.E. 2001. Trawling disturbance can modify benthic production processes. J. Anim. Ecol. 44: 459-475. http://dx.doi.org/10.1046/j.1365-2656.2001.00504.x

Jennings S., Nicholson M., Dinmore T., Lancaster, J. 2002. Effects of chronic trawling disturbance on the production of infaunal communities. Mar. Ecol. Progr. Ser. 243: 251-260. http://dx.doi.org/10.3354/meps243251

Kaiser M.J., Rogers S.I., Ellis J.R. 1999. Importance of benthic 
habitat complexity for demersal fish assemblages. Am. Fish. Soc. Sym. 22: 212-223

Kaiser, M.J., Ramsay, K., Richardson, C.A., Spence, F.E., Brand, A. R. 2000. Chronic fishing disturbance has changed shelf sea benthic community structure. J. Anim. Ecol. 69(3): 494-503. http://dx.doi.org/10.1046/j.1365-2656.2000.00412.x

Kaiser M., Clarke K., Hinz H., Austen, M., Somerfield P., Karakassis I. 2006. Global analysis of response and recovery of benthic biota to fishing. Mar. Ecol. Prog. Ser. 311: 1-14. http://dx.doi.org/10.3354/meps311001

Koch E.W., Barbier E.B., Silliman B.R., Reed D.J., Perillo G.M., Hacker S.D., Granek E.F., Primavera J.H., Muthiga N., Polasky S., Halpern B.S., Kennedy C.J., Kappel C.V, Wolanski E. 2009. Non-linearity in ecosystem services: temporal and spatial variability in coastal protection. Front. Ecol. Environ. 7(1): 29-37. http://dx.doi.org/10.1890/080126

Lleonart J., Maynou F. 2003. Fish stock assessments in the Mediterranean : state of the art. Sci. Mar. 67: 37-49.

Lohrer A.M., Thrush S.F., Gibbs M.M. 2004. Bioturbators enhance ecosystem function through complex biogeochemical interactions. Nature 431(7012): 1092-1095. http://dx.doi.org/10.1038/nature03042

Lohrer A. M., Chiaroni L. D., Hewitt J. E., Thrush S. F. 2008. Biogenic disturbance determines invasion success in a subtidal soft-sediment system. Ecology 89(5): 1299-1307. http://dx.doi.org/10.1890/07-0421.1

Lombarte A., Recasens L., González M., Gil de Sola L. 2000. Spatial segregation of two species of Mullidae in relation to habitat. Mar. Ecol. Prog. Ser. 206: 239-249. http://dx.doi.org/10.3354/meps206239

Lukoschek V., McCormick M. 2001. Ontogeny of diet changes in a tropical benthic carnivorous fish. Parupeneus barberinus (Mullidae): relationship between foraging behaviour, habitat use, jaw size, and prey selection. Mar. Biol. 138(6): 1099-1113. http://dx.doi.org/10.1007/s002270000530

Machias A., Labropoulou M. 2002. Intra-specific variation in resource use by red mullet, Mullus barbatus. Estuar. Coast. Shelf Sci. 55(4): 565-578. http://dx.doi.org/10.1006/ecss.2001.0924

Martín P., Sartor P., Garcia-Rodriguez M. 1999. Exploitation patterns of the European hake Merluccius merluccius, red mullet Mullus barbatus and striped red mullet Mullus surmuletus in the western Mediterranean. J. Appl. Ichthyol. 15(1): 24-28. http://dx.doi.org/10.1046/j.1439-0426.1999.00125.x

Martín P., Muntadas A., de Juan S., Sánchez P., Demestre M. 2014. Performance of a North Western Mediterranean bottom trawl fleet: How the integration of landings and VMS data can contribute to the implementation of ecosystem-based fi sheries management. Mar. Policy 43: 112-121. http://dx.doi.org/10.1016/j.marpol.2013.05.009

Planes S., García-Charton J.A., Pérez-Ruzafa A. (Coord.), 2006. Ecological effects of Atlanto-Mediterranean Marine Protected Areas in the European Union. EMPAFISH Project, Booklet, $1158 \mathrm{pp}$

Queirós A.M., Hiddink J.G., Kaiser M.J., Hinz H. 2006. Effects of chronic bottom trawling disturbance on benthic biomass, production and size spectra in different habitats. J. Exp. Mar. Bio. Ecol. 335(1): 91-103.
Ohttp://dx.doi.org/10.1016/j.jembe.2006.03.001

Rijnsdorp A., Vingerhoed B. 2001. Feeding of plaice Pleuronectes platessa $\mathrm{L}$. and sole Solea solea (L.) in relation to the effects of bottom trawling. J. Sea Res. 45(3-4): 219-229. http://dx.doi.org/10.1016/S1385-1101(01)00047-8

Rumohr H., Kujawsky T. 2000. The impact of trawl fishery on the epifauna of the southern North Sea. ICES J. Mar. Sci. 57(5): 1389-1394. http://dx.doi.org/10.1006/jmsc.2000.0930

Sánchez P., Demestre, M., Martín P. 2004. Characterisation of the discards generated by bottom trawling in the northwestern Mediterranean. Fish. Res. 67(1): 71-80 http://dx.doi.org/10.1016/j.fishres.2003.08.004

Sánchez P., Sartor P., Recasens L., Ligas A., Martin J., de Ranieri S., Demestre M. 2007. Trawl catch composition during different fishing intensity periods in two Mediterranean demersal fishing grounds. Ecologia 71(4): 765-773.

Sardá R., Pinedo S., Martin D. 1999. Seasonal dynamics of macroinfaunal key species inhabiting shallow soft-bottoms in the Bay of Blanes (NW Mediterranean). Acta Oecologica 20(4): 315-326. http://dx.doi.org/10.1016/S1146-609X(99)00135-6

Smith C. 2000. Impact of otter trawling on an eastern Mediterranean commercial trawl fishing ground. ICES J. Mar. Sci. 57(5): 1340-1351. http://dx.doi.org/10.1006/jmsc.2000.0927

Thrush S. F., Dayton P. K. 2002. Disturbance to marine benthic habitats by trawling and dredging: Implications for Marine Biodiversity. Annu. Rev. Ecol. Syst. 3(1): 449-473. http://dx.doi.org/10.1146/annurev.ecolsys.33.010802.150515

Thrush S.F., Hewitt J. E., Cummings V. J., Dayton P. K., Cryer M., Turner S. J., Funnell G. A., Budd R. G., Milburn, C. J., Wilkinson, M. R. 1998. Disturbance of the Marine Benthic Habitat by Commercial Fishing : Impacts at the Scale of the Fishery. Ecol. Appl. 8(3): 866-879.

http://dx.doi.org/10.1890/1051-0761(1998)008[0866:DOTMB $\mathrm{H}] 2.0 . \mathrm{CO} ; 2$

Thrush S., Hewitt J., Funnell G., Cummings V., Ellis J., Schultz D., Talley D., Norkko A. 2001. Fishing disturbance and marine biodiversity: role of habitat structure in simple soft-sediment systems. Mar. Ecol. Progr. Ser. 221: 255-264 http://dx.doi.org/10.3354/meps221255

Thrush S. F., Hewitt J. E., Lohrer A. M., Chiaroni, L. D. 2013. When small changes matter: the role of cross-scale interactions between habitat and ecological connectivity in recovery. Ecol. appl. 23(1): 226-238. http://dx.doi.org/10.1890/12-0793.

Tserpes G., Fiorentino F., Levi D., Cau A., Murenu M., Zamboni A., Papaconstantinou C. 2002. Distribution of Mullus barbatus and M. surmuletus (Osteichthyes: Perciformes) in the Mediterranean continental shelf: implications for management. Sci. Mar. 66: 39-54.

Zajac R. 2003. Community and population-level responses to disturbance in a sandflat community. J. Exp. Mar. Bio. Ecol. 294(1): 101-125. http://dx.doi.org/10.1016/S0022-0981(03)00262-4 